\title{
Ternimaidon laatu ja laatuun vaikuttavat tekijät itäsuomalaisilla lypsykarjatiloilla
}

\author{
Elina Kananen ${ }^{2}$, Marja Viitala ${ }^{1}$, Arja Korhonen ${ }^{1}$, Petri Kainulainen ${ }^{1}$, Pirjo Suhonen ${ }^{1}$ \\ 1)Savonia-ammattikorkeakoulu, PL 72, 74101 Iisalmi, etunimi.sukunimi@ savonia.fi \\ 2) elina kananen@ hotmail.com \\ 3) maikki.viitala@gmail.com
}

\section{TIIVISTELMÄ}

Kestävän ja pitkäaikaisen lehmän pohja luodaan jo vasikkavaiheessa ja siksi alkukasvatuksen merkitys on hyvin tärkeää. Vasikka syntyy ilman immuniteettiä eli sillä ei ole vasta-aineita taudinaiheuttajia vastaan, koska lehmän istukka ei läpäise vasta-aineita emän verestä sikiöön. Vasta-aineet eli immunoglobuliinit ( $\operatorname{IgG})$ vasikka saa syntymänsä jälkeen hyvälaatuisesta emän ternimaidosta.

Suomessa ei ole toteutettu aikaisemmin ternimaidon laatuun liittyvää tutkimusta ja siksi tässä työssä haluttiin selvittää, minkä laatuista ternimaitoa itäsuomalaisten lypsykarjatilojen lehmät lypsävät ja löytyykö tekijöitä, jotka oleellisesti vaikuttavat ternimaidon laatuun. Tutkimus tehtiin osana Kestävä karjatalous -hanketta. Lypsykarjatiloihin oltiin yhteydessä ItäMaidon tuottajakirjeen kautta sekä osaan tiloista suoralla kontaktilla. Tutkimukseen osallistui 103 maitotilaa.

Tutkimuksesta kiinnostuneille tiloille lähetettiin kyselykaavakkeet sekä ternimaitonäytteitä varten tarvikkeet. Tutkimuksen aluksi suoritettiin pilottikoe, jossa kerättiin maitotiloilta 49 ensimmäisen lypsyn ternimaitonäytettä ( $40 \mathrm{dl} \mathrm{ja} 10 \mathrm{ml}$ näytteet), joista $4 \mathrm{dl}$ näytteiden avulla testattiin ternimaitotutkimukseen soveltuvat laitteet (kolostrometri ja Brix $32 \%$-refraktometri). Pienemmät $10 \mathrm{ml}: n$ näytteet tutkittiin Movetin Kuopion laboratoriossa, josta saatiin vertailukelpoiset tulokset refraktometrille ( $r=0.86$ ). Varsinaisessa tutkimuksessa tutkittiin 1232 ternimaitonäytettä refraktometrin avulla 103 maitotilalta ja selvitettiin laatuun vaikuttavia tekijöitä tilojen täydentämien taustatietokaavakkeiden avulla. Taustatiedot käsiteltiin Webropol-kyselytyökalulla. Tuottajat ottivat ternimaitonäytteet mahdollisimman pian poikimisen jälkeen ensimmäisestä lypsystä ja pakastivat näytteet. Pakastetut näytteet noudettiin tiloilta myöhemmin analysoitavaksi.

Brix \%:n arvot vaihtelivat $6 \%$ - $32 \%$ :iin, ka 21,3\%. Tavoitteellinen Brix \% -tulos on $22 \%$, jolloin ternimaito on laadultaan hyvää ja sisältää $50 \mathrm{~g} / \mathrm{l}$ immunoglobuliinejä . Lehmän poikimakerralla näyttäisi olevan vaikutusta ternimaidon vasta-ainepitoisuuteen $(\mathrm{p}=0,001)$. Vasta-ainepitoisuudeltaan hyvälaatuista ternimaitoa tuottivat 4 tai yli 4 kertaa poikineet lehmät. Lehmän rodulla todettiin olevan myös vaikutusta vasta-ainepitoisuuteen $(\mathrm{p}=0,003)$. Holstein-rotuisilla vasta-ainepitoisuus oli keskimäärin korkeampi kuin muilla roduilla.

Saatujen tulosten perusteella ternimaidon laatua tulisi ehdottomasti tutkia tiloilla, koska ternimaidon laatu vaihteli kovasti lehmien välillä. Vastasyntyneelle vasikalle tulisi antaa vain hyvälaatuista ternimaitoa mahdollisimman pian syntymästä ja riittävän paljon, jotta vasikan hyvä alkulähtö elämään olisi turvattu.

Asiasanat: ternimaito, vasta-aineet, lehmä, vasikat, refraktometri 


\section{Johdanto}

Kestävän lehmän pohja luodaan jo vasikkavaiheessa ja alkukasvatuksen merkitys on hyvin tärkeä. Alkukasvatusvaiheessa vasikalle on tärkeää juottaa hyvälaatuista ternimaitoa. Ternimaito sisältää paljon ravinteita, kuten rasvaa, valkuaista, vitamiineja ja vasta-aineita. Lisäksi vasikka saa ternimaidosta vastaaineita taudinaiheuttajia vastaan. Riittävä vasta-aineiden saanti on erittäin tärkeää vasikalle, koska vasikka syntyy ilman aktiivista immuniteettia.

Suomessa on tehty vain vähän ternimaidon laatuun liittyvää tutkimusta. Kesto eli Kestävä karjatalous - hankkeessa selvitettiin ternimaidon vasta-aineiden ja vasikkakuolleisuuden yhteyttä (Neuvonen ja Oksaman 2012). Tässä tutkimuksessa kohteena olivat itäsuomalaisten lypsykarjojen ternimaidon laatu. Kohdealueena oli maidontuotannon kannalta merkittävä alue Suomessa. Suomessa vuonna 2012 tuotosseurantaan kuului 6870 lypsykarjatilaa, joiden keskikarjakoko oli 33,1 lehmää. Lehmistä 60,8 \% oli rodultaan ayrshirejä, 37,8 \% lehmistä oli holsteineja sekä suomenkarjaa 1,2 \%. Nautakarjataloutta on eniten Pohjois-Savossa ja Pohjanmaan alueella. Lypsylehmiä vuonna 2012 oli Pohjois-Savossa 38 300, Etelä-Savossa 14 200, Kainuussa 8100 ja Keski-Suomessa 14 300. (Tietopalvelukeskus, 2013)

Ternimaitonäytteitä sekä taustatietoja kerättiin lokakuusta 2013 kesäkuun alkuun 2014 saakka. Tiloille lähetettiin maitonäyteputkia ja kaavakkeita postissa. Kaavakkeita oli kaksi erilaista, tila- ja eläinkohtainen kaavake. Tila kaavake täytettiin yhden kerran ja eläinkohtainen kaavake jokaista erillistä maitonäytettä kohden. Kaavakkeet kerättiin samalla kun maitonäytteet haettiin tiloilta.

Tutkimuksen tavoitteena oli saada selville, minkä laatuista ternimaitoa lypsylehmät tuottavat vasikoilleen Itä-Suomen alueella. Lisäksi haluttiin löytää tekijöitä, jotka oleellisesti vaikuttavat ternimaidon laatuun. Tutkimus tuottaa tietoa, jonka pohjalta karjatilalliset voivat pyrkiä parantamaan ternimaidon laatua. Tutkimuksesta on erityisesti hyötyä karjatilallisille, joilla on ollut ongelmia vasikoiden terveyden ja kehityksen kanssa.

\section{Aineisto ja menetelmät}

Ternimaitotutkimuksen aineisto kerättiin kaavakekyselynä ja ternimaitonäytteinä. Kyselykaavakkeet lähetettiin tiloille ja pääosin noudettiin tiloilta yhdessä pakastettujen ternimaitonäytteiden kanssa. Aineisto oli numeerinen ja osittain sanallinen. Taustahypoteesina oli, että vanhemman lehmän ternimaito on paremman laatuista eli sisältää enemmän vasta-aineita kuin ensikon ternimaito.

Laatua tutkittiin Brix $0-32 \%$ refraktometrillä, jolla selvitettiin lehmän ternimaidon vasta-ainepitoisuus (FinnLacto). Tavoitteena oli saada 1000 ensimmäisen lypsyn ternimaitonäytettä, näytteitä kertyi 1232 kappaletta. Näytteisiin oli merkitty tarvittavat tiedot ja näytteet oli pakastettu mahdollisimman pian näytteenoton jälkeen. Näytteet haettiin sovittuna ajankohtana tiloilta tai vastaanotettiin Savonia- ammattikorkeakoululla sovittuna ajankohtana.

Näytteet otettiin ensin sulamaan telineisiin. Telineisiin mahtui yhtäaikaisesti 42 maitonäytettä. Maitonäytteiden sulamiseen $21-22$ asteiseksi meni noin kolme tuntia. Tässä vaiheessa refraktometri kalibroitiin akkuvedellä. Pipetillä laitettiin akkuvettä noin viisi tippaa refraktometrin valolevyn alle tasaisesti. Refraktometrillä katsottiin valon lähdettä kohti, kalibrointi tulokseksi piti saada nolla. Kalibraatioruuvia pyöritettiin niin, että tulokseksi saatiin nolla. Refraktometrin valolevy kuivattiin paperilla. Jokaisen näytteen lämpötila tarkistettiin ja merkattiin ylös tutkimusvihkoon. Mittauslämpötila oli keskimäärin 21,6 astetta.

Maitonäyteputkea kierrettiin ylösalaisin viisi kertaa, jotta maidon pintaan kertynyt rasva saatiin sekaisin. Puhtaalla pipetillä otettiin maitoa näyteputkesta ja laitettiin valolevyn alle viisi tippaa tasaisesti. Valolevy asetettiin maidon päälle, niin ettei ilmakuplia jäänyt maitoon. Tulos luettiin Brix- \% asteikolta katsomalla refraktometrillä valon lähdettä kohti. Tulokset kirjattiin tutkimusvihkoon. Refraktometri puhdistettiin ensin kuivalla paperilla, jonka jälkeen vielä kostutetulla paperilla. Käytetyt pipetit ja likaiset paperit laitettiin roskiin. Testauksen jälkeen maitonäytteet laitettiin mini grip -pusseihin, joissa lukee testauspäivämäärä ja pakastettiin uudelleen.

Laadullisia tekijöitä tutkittiin Webropol- kyselytyökalulla. Webropolissa verrattiin eri vastauksia Brix-tulokseen, jotta löydettäisiin ternimaidon laatuun vaikuttavia tekijöitä. Tutkimuksen analysointiin käytettiin $\mathrm{t}$-testiä, varianssianalyysiä ja ristiintaulukointia. Käytettävä analyysimenetelmä valittiin saatujen vastauksien perusteella. 


\section{Tulokset ja tulosten tarkastelu}

Refraktometrilla mitatut Brix \% -arvojen keskiarvo oli 21,3\%, vaihteluvälillä 6 - $32 \%$. Tavoitteena oli $22 \%$ tai enemmän, jolloin ternimaidon laatu on hyvä. Tuloksen jäädessä alle $20 \%$ ternimaidon laatu on huonoa. Tuloksen ollessa yli $32 \%$ ternimaidon laatu on erinomainen.

Ternimaidon vasta-ainepitoisuuteen oli tilastollisesti merkittävää vaikutusta $(\mathrm{p}<0.05)$ poikimakerralla, lehmän rodulla, ummessaolokauden pituudella, ternimaidon lypsytavalla sekä näytteen säilytysajalla ennen pakatusta. Vanhempien lehmien ternimaidon laatu oli ennakko-odotusten mukaisesti paras (Taulukko 1). Holstein - rotuisten lehmien ternimaito osoittautui laadukkaammaksi kuin muiden rotujen lehmillä (Taulukko 2). Ryhmässä muut oli pääasiassa suomenkarjan lehmiä. Ummessaolokauden pituuden vaikutuksen tutkimista varten umpikausi jaettiin kolmeen luokkaan (alle 60 päivää, 60-80 päivää ja yli 81 päivää). Lypsyrobotilta kerättyjen ternimaitonäytteiden laatu oli tässä tutkimuksessa muita lypsytapoja alhaisempi (Taulukko 3). Taulukossa 4 esitetään säilytysajan vaikutus ternimaidon laatuun. Näytteen nopea pakastaminen paransi tuloksia.

Taulukko 1. Poikimakerran vaikutus vasta-ainepitoisuuteen.

\begin{tabular}{lll}
\hline Poikimakerta & N & Brix- $\%$ \\
\hline 1 & 428 & 20,6 \\
2 & 320 & 20,7 \\
3 & 204 & 21,8 \\
4 & 106 & 22,9 \\
yli 4 & 140 & 22,9 \\
\hline Yhteensä & 1198 & 21,3 \\
\hline
\end{tabular}

Taulukko 2. Ternimaidon vasta-ainepitoisuus roduittain.

\begin{tabular}{lll}
\hline Rotu & N & Brix- $\%$ \\
\hline ayrshire & 608 & 20,8 \\
holstein & 540 & 22,0 \\
Muut & 39 & 19,2 \\
\hline Yhteensä & 1187 & 21,3 \\
\hline
\end{tabular}

Taulukko 3. Näytteenoton lypsytavan vaikutus Brix- \% tulokseen.

\begin{tabular}{lllll}
\hline Näytteenottotapa & Käsin & Koneella & Lypsyrobotilla & Yhteensä \\
\hline $\mathrm{N}$ & 282 & 601 & 316 & 1199 \\
Brix- $\%$ & 22,3 & 21,3 & 20,5 & 21,3 \\
\hline
\end{tabular}

Taulukko 4. Säilytysajan vaikutus Brix- \% tulokseen.

\begin{tabular}{lllllll}
\hline Säilytysaika & alle $0,5 \mathrm{~h}$ & $0,5-1 \mathrm{~h}$ & $1-2 \mathrm{~h}$ & $2-17 \mathrm{~h}$ & yli $24 \mathrm{~h}$ & Yhteensä \\
\hline $\mathrm{N}$ & 385 & 303 & 265 & 180 & 6 & 1139 \\
Brix- \% & 21,8 & 21,0 & 21,2 & 21,2 & 17,0 & 21,3 \\
\hline
\end{tabular}

\section{Johtopäätökset}

Poikimakertojen määrä vaikuttaa vasta-ainepitoisuuteen. Tuloksien perusteella voidaan todeta, että neljä tai yli neljä kertaa poikineet lehmät tuottavat keskimäärin vasta-ainepitoisuudeltaan hyvälaatuista ternimaitoa. Lehmät, jotka ovat poikineet yhden tai kaksi kertaa, tuottavat keskimäärin vasta-ainepitoisuudeltaan heikkolaatuisempaa ternimaitoa. Vanhemmat lehmät ovat luultavasti kohdanneet enemmän taudinaiheuttajia elämänsä aikana ja niille on kehittynyt parempi vastustuskyky.

Holstein-rotuisilla lehmillä näyttäisi olevan parempi laatuista ternimaitoa kuin muilla. Ayrshire lehmien ternimaidon vasta-ainepitoisuus oli tyydyttävällä tasolla. Muiden rotujen edustajia osallistui 
tähän tutkimukseen huomattavasti vähemmän kuin valtarotuja. Vastaajien pieni määrä voi vaikuttaa saatuun Brix- \%:iin negatiivisesti.

Ummessaolokauden pituudella on vaikutusta ternimaidon vasta-ainepitoisuuteen. Kun lehmä on ollut ummessa yli normaalin ummessaolokauden verran, on vasta-ainepitoisuus parempi kuin vähemmän aikaa ummessaolleilla. Suositeltavaa on kuitenkin pitää lehmä ummessa 60 - 80 päivää. Lehmän vuosikierrolle on tärkeää, että se saa olla ummessa $2-2,5$ kuukautta. Liian pitkä ummessaoloaika altistaa lehmää lihomiselle ja poikimavaikeuksille.

Käsin lypsetyt näytteet on lypsetty sankoon, josta näyte on otettu. Lypsykoneella ja -robotilla lypsetty maito on kiertänyt putkiston läpi ennen kun näyte on otettu maidosta. Putkistossa voi olla ternimaidon laimentavia ainesosia. Ternimaitoa voi laimentaa putkistoon jäänyt maito tai vesi. viitattu 25.1.2015Tulosten perusteella ensimmäinen vasikalle lypsetty ternimaito on hyvä lypsää käsin, koska vasta-aineet säilyvät näin paremmin. Säilytysajan pitkittyessä ennen pakastusta ternimaidon vasta-ainepitoisuus heikkenee, koska bakteerit alkavat tuhota vasta-aineita.

\section{Kirjallisuus}

FinnLacto. Ternimaidon ominaisuuspainomittari. Seinäjoki : FinnLacto Oy.

Neuvonen M., Oksman, A. 2011. Vasikoiden vastustuskyky ja vasikkakuolleisuus. Savonia-ammattikorkeakoulu. [viitattu 25.1.2015]. Saatavissa: http://www.theseus.fi/handle/10024/28425.

Tietopalvelukeskus, Maa- ja metsätalousministeriön. 2013. Maatilatilastollinen vuosikirja 2013. s.l. : Suomen Yliopistopaino Oy, 2013. ISSN0786-2857. 